\title{
HYBRID SWARA-COPRAS METHOD FOR RISK ASSESSMENT IN DEEP FOUNDATION EXCAVATION PROJECT: AN IRANIAN CASE STUDY
}

\author{
Alireza VALIPOUR ${ }^{\mathrm{a}, \mathrm{b}}$, Nordin YAHAYA ${ }^{\mathrm{a}}$, Norhazilan MD NOOR ${ }^{\mathrm{a}}$, \\ Jurgita ANTUCHEVIČIENÉc ${ }^{c}$, Jolanta TAMOŠAITIENE ${ }^{c}$ \\ ${ }^{a}$ Department of Structure and Materials, Faculty of Civil Engineering, Universiti Teknologi Malaysia, \\ Skudai, 81310, Johor, Malaysia \\ ${ }^{b}$ Department of Construction Management, Faculty of Civil engineering Shiraz Branch Islamic Azad University, \\ Shiraz, Iran \\ ${ }^{c}$ Department of Construction Technology and Management, Faculty of Civil Engineering, \\ Vilnius Gediminas Technical University, Sauletekio al. 11, LT-10223 Vilnius, Lithuania
}

Received 05 Sep 2016; accepted 16 Nov 2016

\begin{abstract}
Existing risks in deep foundation excavation projects is a major issue in developing cities. With the rapid increase in the number of various deep foundation and excavation projects in big cities of Iran, many accidents related to deep excavation have been reported every year. These accidents affected delay and increased cost of project implementation. Therefore identification and assessment of risks of these accidents is essential. The aim of the research was to develop a framework to overcome limitations of previous approaches to assess of risks in excavation projects. According to the complexity of a problem and the inherent uncertainty, the framework adopted SWARA (Step-wise Weight Assessment Ratio Analysis) and COPRAS (COmplex PRoportional ASsessment) methods through introducing new criteria for risk assessment. Data was collected through interview, a literature review and a questionnaire survey distributed to excavation project experts. A case study of deep foundation excavation in Shiraz was presented. The results have shown that the risks involving construction safety, unfavourable geological conditions, shortage of managerial experience, incomplete emergency plan and subsidence of ground are the most significant risks excavation projects in Shiraz. The proposed framework and the obtained results can help stakeholders of excavation projects in developing countries better to manage project risks.
\end{abstract}

Keywords: risk assessment, deep foundation, excavation project, COPRAS, SWARA, Shiraz.

\section{Introduction}

Civil construction projects are a mainstay of industries in national economy of Iran as the rapid development of urbanization and the shortage of urban space spurred by the need to build high-rise buildings, subways, tunnels, underground utilities networks, etc. has increased. With increasing population density, number of floors, building parking lots and other surfaces, need to provide services in buildings faced with increasing depth of excavation (Hong et al. 2013). Excavation is considered in economic, safety and technical terms. Excavation projects have become one of the important and challenging issues (Feng, Jun-yan 2011). There are many high risk factors in the construction industry such as deep excavation projects with attention to poor operating conditions compared to various industries (Hong et al. 2013). According to available statistics, accidents in deep excavation have caused property loss, personal injury, and damage to the surrounding environment. Deep excavation projects are consistently at greater risk because there are many complications and uncertainties implicit to these types of projects (Zhou, Zhang 2011). Frequent accidents including accidents in deep excavation projects have occurred in Iran and other countries, causing heavy casualties, huge financial losses, and significant social impacts. Several excavation projects have collapsed (Feng, Jun-yan 2011). For example the Hangzhou Xianghu Station in Metro Line 1 collapsed during construction on 2008, resulting in serious economic losses of more than 50 million Renminbi (Wang 2008), 24 injuries and 21 deaths (Zhang, Li 2008). Guangzhou deep excavation of Haizhucheng collapsed on July 21, 2005. There were 4 people injured and 3 people killed in that accident (Feng, Jun-yan 2011). The excavation of the Mass Rapid Transit Circle Line adjacent to Nicoll Highway in Singapore collapsed in 2004 (Chiew, Yu 2006). 
According to statistics reported, daily surrounding buildings collapse due to non-systematic excavation in Tehran. In May 2013, more than 30 homes were destroyed by non-systematic excavation in Shiraz. One of the biggest factors that cause the problems is lack of knowledge of stakeholders and neglect of the risk of excavation projects. Although excavation is a complex and risky operation, the false idea that the implementation of safety measures used in excavation would be unnecessary in terms of cost and time is still prevalent (Hong et al. 2013). Indeed, risk management is an area with prospects of development and a number of unresolved problems (Aven 2015, 2016). Ensuring quality and safety in excavation projects is a continuous challenge, thus it is essential that a risk management method be developed (Hong et al. 2013). Two types of risk management can be analysed: preventive measures before the start of a project (Leonavičiūtè et al. 2016) and remedial measures once a risk has already occurred (Iqbal et al. 2015). Assessment of risk in building and infrastructure projects applying formal decision making methods can be performed (Zavadskas et al. 2010; Tamošaitienè et al. 2013; Shahata, Zayed 2015). Only through sensible risk assessment techniques can the risks of construction projects including excavation projects be evaluated exactly and the corresponding risks of construction can be controlled (Antucheviciene et al. 2015). The probability of occurrence of risk events can then be reduced and casualties, economic loss and environmental consequences mitigated (Zhou, Zhang 2011). In addition, the lack of a sustainable method, depending on the type and characteristics of the hollow, increases the cost and time factor and timedelayed project and increase the direct and indirect costs, and lack of optimum efficiency effects the project and increase the costs and waste of time and dissatisfaction of the project stakeholders (Li, Wang 2010).

In recent years, many researches and experts analyzed the risk management of excavation projects. Yang et al. (2004) suggested a sketch of the characteristics and concepts of deep foundation excavation risk management, relevant international studies and assessment of the risks grasped. Huang and Bian (2005) proposed some reliable approaches to deep excavation risk management and presented some research on the risks throughout the excavation construction period. Risk assessment methods are also used in deep excavation by researchers. Huang and Bian (2005) prepared the Analytic Hierarchy Process (AHP) and expert investigation methods to assess the risk in deep excavation projects, but their research needed adequate field investigations and experts' experiences. Zhou et al. (2006) have suggested a general integration assessment method to determine the rank of risk by using AHP. In their study, fault tree analysis and AHP were combined in the risk assessment. He et al. (2006) used fault tree analysis to identify the risk factors associated with deep foundation and also investigated a fuzzy synthetic evaluation model to analyse the construction risk.
Hong et al. (2013) investigated risk management of deep foundation excavation based on Risk breakdown structure (RBS) and AHP method in China. Zhou and Zhang (2011) used Bayesian network and fuzzy method to assess risk in deep foundation pit construction in China. Jian et al. (2016) used Rough Set Theory and Catastrophe Progression to calculate the risk probability of foundation pit construction subway station in Tianjin Lingbin road. Khosravizade and Sharifipour (2016) prepared AHP and TOPSIS for assessment of risk in Subway and tunnelling project and they found the landfall and unsystematic excavation were the most important risk. Bo et al. (2015) used Fuzzy Hierarchical risk assessment of Metro Deep Excavation Pit in China.

This paper aims to propose a comprehensive model to identification of risks, and extends the framework for risk assessment based on new criteria for risk assessment. Hybrid SWARA-COPRAS method is adopted for risk prioritization of excavation projects because of its efficiency and capability in handling uncertainty, simulating the ambiguity of human judgment and simultaneous consideration of the ratio to the ideal solution and the ratio with the ideal-worst solution. This study focuses on identification and assessment of risk excavation projects in Iran (Shiraz city) thus bridging these gaps. The findings of this study can help stakeholders of excavation projects (contractor's project owners, contractors and subcontractors) to undertake better risk management, with less excavation damage, cost and time savings, particularly in Iran and other developing countries.

\section{Problem description}

Several excavation projects have failed to achieve budget, deadlines, and quality; most of these projects have been exposed to high risks. Risks must be properly identified, understood and evaluated by Stakeholders. Researchers stated that the impact of risks in completing excavation projects is significant because these risks can be described as uncertain events that have negative effect on project objectives. A proper risk management strategy is essential for controlling and reducing the risks. In this regard, risk assessment is a major component of excavation risk management. Excavation project are diverse and of complex relation and all risk factors are mutually independent and bear a complex and reciprocal influence on the other risk factors. Each risk may be a source of other new risks, or increase the severity of other risks on project objectives. It is necessary to consider interdependencies among various risk events. Thus, to comprehend the potential effect of these risks, the risk evaluation should handle the combined impact of risk events. An accurate assessment of significant risks is important for participants as an input for risk response and control phase that ensure the success of risk management in excavation projects. Research on risk assessment methods illustrates that previous methods used two criteria for ranking of risks, namely the occurrence probabilities and impact of each risk factor, but 
neglect the loss factors. However, the unavailability of comprehensive risk assessment method in deep excavation project makes the risk ranking practice unfeasible and they do not reflect actual and comprehensive situations. Lack of evaluation on detectability, vulnerability, reaction against event, threat of risk ranking in excavation projects is one of the reasons for weak risk assessment of these projects. However, the method of risk management and assessment is always influenced by the uniqueness of the construction industry in different countries. As well, the previous research shows there have been only a few researches and little is known about risk assessment of excavation projects in Iran construction projects. Therefore SWARA-COPRAS as a decision-making method developed for dealing with uncertainties and applied to solve problems of risk assessment in excavation project. The need for modelling uncertainties can be particularly high in applications of MCDM to risk assessment in critical objects.

\section{Research methodology}

The research methodology of this study included four main parts. The first part focused on the identification of risk factors in excavation projects in Shiraz and criteria for risk assessment. This part had been accomplished through conducting a literature review, such as scholarly articles, internet sources, books, documents existing in fire stations and construction companies (NEZAM MOHANDESI) and interview with experts. The second part categorized each risk factor based on type and impact of each risk in excavation projects by using RBS method and interview with experts. The third part focused to obtain weight of each criterion for risk assessment by using SWARA (Step-wise Weight Assessment Ratio Analysis) method. This part includes design and distribution of the questionnaire and analysis of the result obtained from questionnaire by SWARA method. The fourth part focused on assessment of each risk factor in excavation projects. This part includes design and distribution of the questionnaire and analysis by COPRAS (COmplex PRoportional ASsessment) method. The flow of the research methodology for the study is schematically illustrated in Figure 1.

\subsection{Sample size}

In this study, the sample involved the experts in deep foundation excavation projects in Iran. The random sampling technique is utilized when there is an equal geographic distribution among samples. The sample size that represented the population for the questionnaire was determined using the following formula (Al-Tmeemy et al. 2012):

$$
S S=\frac{z^{2} p(1-p)}{c^{2}},
$$

where $S S$ is the calculated sample size, $z$ is $z$ value for the confidence level, $p$ is percentage picking a choice, expressed as decimal, $c$ is confidence interval. The calculated sample size $(S S)$ was then corrected for finite population using Eqn (2):

$$
\text { Corrected } S S=\frac{S S}{1+\left(\frac{S S-1}{p o p}\right)},
$$

where $p o p$ is population. Later, the corrected sample size (Corrected SS) was adjusted for the response rate using Eqn (3):

$$
\text { Corrected SS for } r r=r r \times \text { corrected } S S \text {, }
$$

where $r r$ is a response rate.

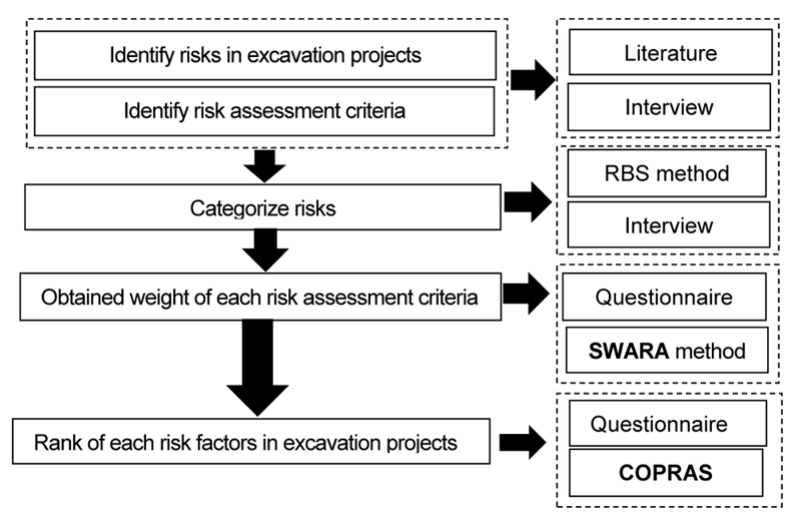

Fig. 1. Research methodology

\subsection{Questionnaire}

The questionnaire survey was conducted as a secondary resource to collect data for this study. Two types of questionnaires were used in this study. Questionnaire type A was designed to obtain the weight of each risk assessment criteria based on excavation projects. Questionnaire type $\mathrm{B}$ was designed to obtain the rank of each risk in excavation projects. The first section provided general information regarding the respondents such as years of experience in excavation construction projects, type of project involved, type of role in the project and background information about the individual completing the questionnaire. The second part included the main questions about the weight of each risk assessment criteria and ranking of each risk. The 5-point Likert scale is represented as $1=$ Very Low; 2 = Low; $3=$ On Average; $4=$ High; and $5=$ Very High.

\subsection{Step-Wise Weight Assessment Ratio Analysis (SWARA) method}

The Step-Wise weight Assessment Ratio Analysis (SWARA) method was developed and applied for the selection of rational dispute resolution method in 2010 (Keršulienè et al. 2010). This method is helpful for coordinating and gathering data from experts. Some researchers developed decision-making models based on SWARA in recent years that have been mentioned in several publications: Karabasevic et al. (2015), Turskis et al. (2016), Nakhaei et al. (2016), etc. 
In the current study, the SWARA method was applied for determining the weight of each risk assessment criterion. Each expert prioritized and ranked each risk assessment criterion from the first to the last one. In this method, the most significant criterion obtained the first rank (1), and the least significant criterion obtained the last rank (12). The average value of ranks was used for determining the overall ranking of the group of experts (Keršulienė, Turskis 2011).

\subsection{COPRAS (Complex Proportional Assessment) method}

Zavadskas and Kaklauskas (1996) described the mathematic concept and introduced the COPRAS method. Currently this method is one of the well-known MCDM methods, which selects the best alternative between a lot of feasible alternatives by determining a solution with direct and proportional ratio to the best solution to the ratio with the ideal-worst solution. Some recent decisionmaking models based on COPRAS were developed in fuzzy environment. While, in the current research we apply initial COPRAS method, criteria weights and alternatives ratings are taken into account as crisp numerical data (Kundakc1, Iş̧1k 2016; Mulliner et al. 2016, etc.).

\section{The application of the proposed model}

The purpose of this study is to apply a hybrid MCDM model for assessment of risks in foundation excavation project in Shiraz (city of Iran). Four case studies, that had been built or are still under construction, were selected for this study. For this period of the research, 150 experts were identified. In this paper, SWARA and COPRAS methods are employed as an integrated methodology for assessment of risk factors in foundation excavation projects.

\subsection{Case study}

Shiraz is one of the major cities in Iran and is the capital of Fars province. The last census in 2012 recorded a population of over 1,500,000 people. The city of Shiraz in Fars province is located at an altitude of 1486 meters above sea level in the mountainous region of Zagros and features a moderate climate. City expansion is limited by the Drake Mountains to the west, and from the Bamou, Sabzposhan, Chehelmagham and Babakohi mountains (the mountains of Zagros) to the north. According to the latest urban city report, administrative divisions are divided into 9 independent areas covering over 178,891 square kilometres. The development of high-rise buildings and underground building is extremely important in Shiraz as a developing city in Iran with diverse geographical conditions. The deep foundation excavation has developed due to the shortage and high cost of land in Shiraz. Many accidents occur in foundation excavations in Shiraz every year, resulting in great loss of life and in stakeholder asset values. Therefore, it is necessary to carry out effective risk assessment on foundation excavation projects.

\subsection{Sample size}

The sample size that represents the population in response to the questionnaire is calculated based on Eqn (1). In the paper, the targeted size of population is 150 experts involved in deep foundation excavation projects in Iran. For the purpose of getting the maximum sample size, the value of $p$ was taken as 0.5 . The confidence level $z$ was taken to be $95 \%$, and the maximum standard error allowed, $c$ in this study, was taken as $10 \%$. Applying the above formula, the sample size was calculated using a Microsoft Excel work sheet, and the results are listed in Table 1.

Table 1. Sample size calculation

\begin{tabular}{lcc}
\hline \multicolumn{1}{c}{ Percentage $(p)$} & 0.5 & \\
\hline Confidence interval $(c)$ & 0.1 & 0.975 \\
Confidence level and $z$ value & $95 \%$ & 1.96 \\
Response rate $(r r)$ & $92 \%$ & - \\
Population & 150 & - \\
Total & & 54 \\
\hline
\end{tabular}

In this study, 150 experts from Iran that are involved in excavation projects, including main and subcontractors, a deputy director, project managers, quality managers, technical directors and academic person were selected. The experts had to meet two criteria before being invited to participate in the survey: first, they needed to have extensive work experience within the construction projects of Iran; and second, they needed to be involved in the management of excavation projects or have gained in-depth knowledge of the deep foundation excavation through research. A total of 89 duly completed survey forms were returned in June 2015, representing a response rate of 59.33\%. Among these 89 responses, 24 responses were declared invalid due to blank, illegible, invalid, or multiple answers. Based on sample size of 54, the 65 returned and valid questionnaires were deemed as adequate and reliable for the purposes of this research. Table 2 shows the background information of the respondents.

\subsection{Identification and assessment of criteria for risk assessment}

Risk assessment criteria identification is the first step in risk assessment excavation projects. In order to identify risk assessment criteria, a decision-making group comprised of project manager, quality manager, main contractor, sub-contractor, a deputy director, technical director and foundation excavation project contractor was established. The primary result of this step was to collect data through the interview by experts and the previous studies on foundation excavation and risk assessment articles in construction projects such as Zegordi et al. (2012), Valipour et al. (2015), Hong et al. (2013), Sarvari et al. (2014). Risk assessment criteria can be categorized as beneficial and non-beneficial (cost). Among these 12 cri- 
Table 2. Background information of the selected experts

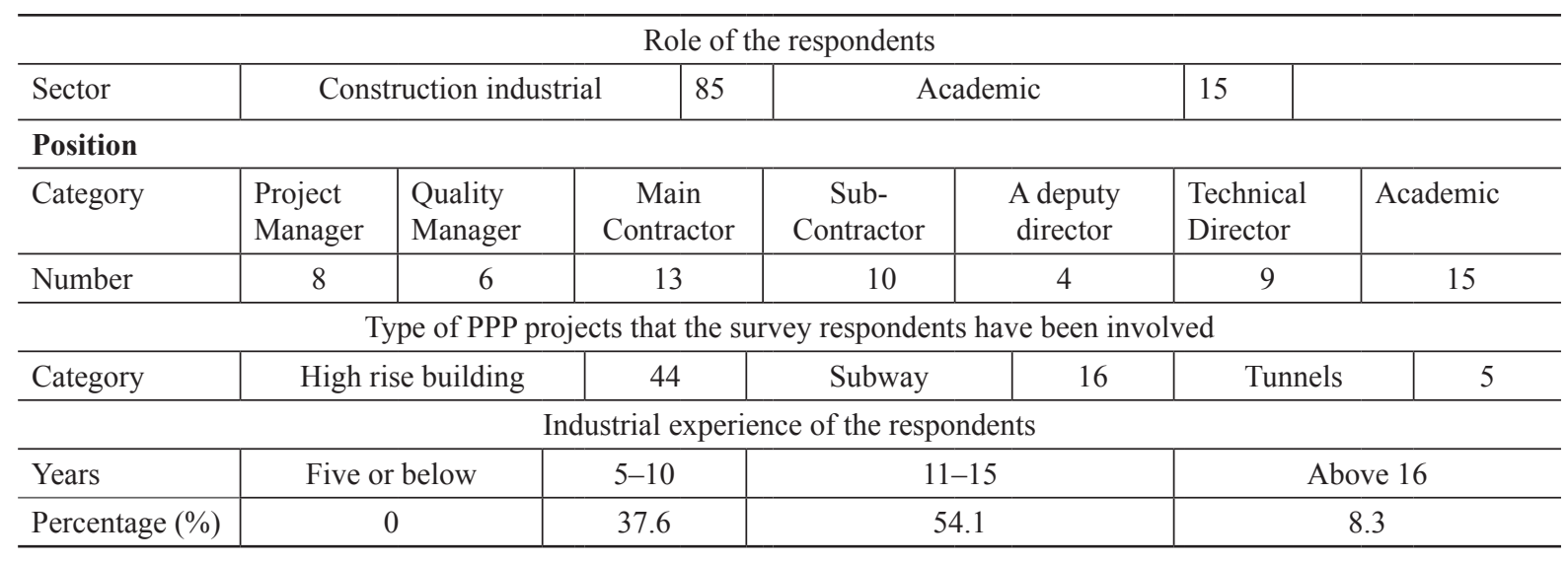

Table 3. Risk assessment criteria

\begin{tabular}{l|l|l}
\hline \multicolumn{1}{c|}{ Risk assessment criteria } & \multicolumn{1}{c}{ Description } & \\
\hline$C_{1}:$ Vulnerability & Vulnerability and weakness of an asset that can convert it into an event & Cost $(-)$ \\
\hline$C_{2}:$ Threat & $\begin{array}{l}\text { Threat is defined as an event with an undesired the potential impact on a project } \\
\text { objective (time, cost, quality) }\end{array}$ & Cost $(-)$ \\
\hline$C_{3}:$ Consequence & Consequence is defined as the effect of an event or incident & Cost $(-)$ \\
\hline$C_{4}:$ Risk uniqueness & When dealing with a special subject, a risk may receive particular attention & Cost $(-)$ \\
\hline$C_{5}:$ Risk uncertainty & $\begin{array}{l}\text { The lack of information about the nature of the probability distribution function of } \\
\text { risk measures }\end{array}$ & Cost $(-)$ \\
\hline$C_{6}:$ Risk proximity & Risk proximity is the interval during which the risk is expected to occur & Cost $(-)$ \\
\hline$C_{7}:$ Risk coupling & The effect that a risk would have on measures of other risks & Cost $(-)$ \\
\hline$C_{8}:$ Detectability & The capability and potential for identification and elimination of the weakness & Benefit $(+)$ \\
\hline$C_{9}:$ Reaction against event & The capability of an appropriate response in order to reduce & Benefit $(+)$ \\
\hline$C_{10}:$ Risk manageability & The degree of manageability for control and influence of a given risk & Benefit $(+)$ \\
\hline$C_{11}:$ Risk probability & The degree of the likelihood that each risk will occur & Benefit $(+)$ \\
\hline$C_{12}:$ Risk predictability & This measure determines where and when in the project the risk might occur & Benefit $(+)$ \\
\hline
\end{tabular}

teria 7 criteria are non-beneficial (cost), namely $C_{1}, C_{2}$, $C_{3}, C_{4}, C_{5}, C_{6}$ and $C_{7}$, and 5 criteria are beneficial, namely $C_{8}, C_{9}, C_{10}, C_{11}$ and $C_{12}$. Beneficial criteria are maximized, whereas non-beneficial criteria are minimized. As a result, 12 risks assessment criteria were identified and showed in Table 3.

In the next step, SWARA is applied to obtain the weight of each criterion (Keršuliene et al. 2010). Therefore, the questionnaire design was based on SWARA method and distributed by email between the experts in excavation projects that have been identified. Based on their own experiences and implicit knowledge, each expert was asked to rank the importance of each criterion. Experts' ideas were collected and the outcome shown in Table 4. Outcome of this step will be used in COPRAS method for assessment of risks.

Based on the results from SWARA, among 12 risk assessment criteria, the five highest criteria score of $0.1346,0.1140,0.1,0.0893$ and 0.080 were Threat $\left(C_{2}\right)$, Consequence $\left(C_{3}\right)$, Risk manageability $\left(C_{10}\right)$, Risk probability $\left(C_{11}\right)$ and Risk coupling $\left(C_{7}\right)$, respectively.

\subsection{Risk identification and assessment}

Risk identification was the next step for this study after identification and determining the weight of each risk assessment criteria by SWARA method. Therefore, a review of books and journal papers relevant to excavation projects were also adopted to collect primary data for identification of risk factors. Data were collected through the previous studies on foundation excavation projects such as Hong et al. (2013), Feng and Jun-yan (2011), Zhang (2010), Li and Wang (2010), Zhou and Zhang (2011), Zhang et al. (2016) and Burcar Dunovic et al. (2016). The interview with experts in excavation project was the next approach to identify significant risks. Risk breakdown structure (RBS) and interview with experts were used to classify risks based on the risk impact and resources on the project objectives. 37 risks were then grouped into seven categories by expert judgments with the help of the Delphi method. Table 6 shows the significant risk factors in excavation projects in Iran. Risk assessment was the last part of this study and COPRAS method was applied for this part (Zavadskas, Kaklauskas 1996). A question- 
Table 4. Weight of each risk assessment criteria

\begin{tabular}{|c|c|c|c|c|c|}
\hline Criteria & $\begin{array}{l}\text { Comparative importance of average value } \\
\qquad S_{j}\end{array}$ & $\begin{array}{l}\text { Coefficient } \\
K_{j}=s_{j}+1\end{array}$ & $\begin{array}{l}\text { Recalculated } \\
w_{j}=\frac{x_{j-1}}{k_{j}}\end{array}$ & $\begin{array}{c}\text { Weight } \\
q_{j}=\frac{w_{j}}{\sum w_{j}}\end{array}$ & Rank \\
\hline$C_{2}$ & - & 1 & 1 & 0.1346 & 1 \\
\hline$C_{3}$ & 0.18 & 1.18 & 0.8474 & 0.1140 & 2 \\
\hline$C_{10}$ & 0.14 & 1.14 & 0.7433 & 0.1 & 3 \\
\hline$C_{11}$ & 0.12 & 1.12 & 0.6637 & 0.0893 & 4 \\
\hline$C_{7}$ & 0.105 & 1.105 & 0.6 & 0.080 & 5 \\
\hline$C_{12}$ & 0.09 & 1.09 & 0.5510 & 0.0741 & 6 \\
\hline$C_{5}$ & 0.085 & 1.085 & 0.5078 & 0.0683 & 7 \\
\hline$C_{1}$ & 0.08 & 1.08 & 0.4702 & 0.0633 & 8 \\
\hline$C_{4}$ & 0.074 & 1.074 & 0.4392 & 0.0591 & 9 \\
\hline$C_{6}$ & 0.055 & 1.055 & 0.4163 & 0.0560 & 10 \\
\hline$C_{8}$ & 0.03 & 1.03 & 0.4042 & 0.0544 & 11 \\
\hline$C_{9}$ & 0.022 & 1.022 & 0.3955 & 0.0532 & 12 \\
\hline
\end{tabular}

naire survey based on COPRAS method was designed and distributed to experts by email. In this section, respondents were asked to express their perceptions of the importance of 37 foundation excavation risks based on previous similar studies. At this stage of the application, the group of experts' assesses each risk factors according to each criteria. The sums of the weighted normalized values for the beneficial criteria $\left(p_{i+}\right)$ and for the nonbeneficial criteria $\left(p_{i-}\right)$ are calculated. Table 5 presents COPRAS result for beneficial and non-beneficial criteria.

Then the relative significance or priority value $\left(Q_{i}\right)$ and the quantitative utility $\left(N_{i}\right)$ for each alternative are calculated and as shown in Table 6.
According to the calculation results, the final ranking of each risk factor using COPRAS method is presented in Table 6 . The top risk was management of safety in construction $\left(R_{41}\right)$ with weight of 0.1190 . The second and third risks were unfavourable geological conditions $\left(R_{61}\right)$, managerial experience shortage $\left(R_{44}\right)$ with scores of 0.11644 and 0.0868 respectively. The fourth and fifth ranks of each risk with scores of 0.08598 and 0.02729 respectively were incomplete emergency plan $\left(R_{47}\right)$ and subsidence of ground $\left(R_{14}\right)$. Respondents believed that the lowest ranks of risk in excavation projects were $R_{32}$ and $R_{65}$ with scores of 0.02377 and 0.02372 , respectively.

Table 5. COPRAS result for beneficial and non-beneficial criteria

\begin{tabular}{l|c|c|c|c|c|c|c|c}
\hline Risk & $P i_{+}=\sum_{j=1}^{k} \hat{x}_{i j}$ & $R_{i}=\sum_{j=k+1}^{m} \hat{x}_{i j}$ & Risk & $P i+=\sum_{j=1}^{k} \hat{x}_{i j}$ & $R_{i}=\sum_{j=k+1}^{m} \hat{x}_{i j}$ & Risk & $P i_{+}=\sum_{j=1}^{k} \hat{x}_{i j}$ & $R_{i}=\sum_{j=k+1}^{m} \hat{x}_{i j}$ \\
\hline$R_{11}$ & 0.00728 & 0.01622 & $R_{32}$ & 0.00728 & 0.01924 & $R_{55}$ & 0.00723 & 0.01782 \\
$R_{12}$ & 0.00772 & 0.01838 & $R_{41}$ & 0.09908 & 0.01585 & $R_{61}$ & 0.09890 & 0.01807 \\
$R_{13}$ & 0.00771 & 0.01724 & $R_{42}$ & 0.00661 & 0.01830 & $R_{62}$ & 0.00775 & 0.01760 \\
$R_{14}$ & 0.00672 & 0.15415 & $R_{43}$ & 0.00901 & 0.01866 & $R_{63}$ & 0.00789 & 0.01652 \\
$R_{21}$ & 0.00721 & 0.01844 & $R_{44}$ & 0.06848 & 0.01726 & $R_{64}$ & 0.00782 & 0.01893 \\
$R_{22}$ & 0.00770 & 0.01718 & $R_{45}$ & 0.00901 & 0.01844 & $R_{65}$ & 0.00775 & 0.01986 \\
$R_{23}$ & 0.00795 & 0.01743 & $R_{46}$ & 0.00831 & 0.01713 & $R_{71}$ & 0.00791 & 0.0191 \\
$R_{24}$ & 0.00775 & 0.0175 & $R_{47}$ & 0.06854 & 0.01819 & $R_{72}$ & 0.00772 & 0.01757 \\
$R_{25}$ & 0.00772 & 0.01812 & $R_{48}$ & 0.00791 & 0.01718 & $R_{73}$ & 0.00666 & 0.01622 \\
$R_{26}$ & 0.00776 & 0.01627 & $R_{51}$ & 0.00778 & 0.01641 & $R_{74}$ & 0.00839 & 0.01958 \\
$R_{27}$ & 0.00728 & 0.01866 & $R_{52}$ & 0.00775 & 0.01849 & $R_{75}$ & 0.00772 & 0.01733 \\
$R_{28}$ & 0.00791 & 0.01918 & $R_{53}$ & 0.00774 & 0.01935 & & & \\
$R_{31}$ & 0.00772 & 0.01718 & $R_{54}$ & 0.00785 & 0.01957 & & & \\
\hline
\end{tabular}


Table 6. Rank of Significant risk in excavation projects

\begin{tabular}{|c|c|c|c|c|}
\hline Group of risk & Risk factor & $Q_{i}=P_{i}+\frac{\sum_{i=1}^{n} R_{i}}{R_{i} \sum_{i=1}^{n} \cdot \frac{1}{R_{i}}}$ & $N_{i}=\frac{Q_{i}}{Q_{\max }} 100 \%$ & Rank \\
\hline$R_{1}:$ Security risks & $\begin{array}{l}R_{11}: \text { stiffness of retaining structure } \\
R_{12}: \text { strength of retaining structure } \\
R_{13}: \text { upheaval in the bottom } \\
R_{14}: \text { subsidence of ground }\end{array}$ & $\begin{array}{l}0.02682 \\
0.02498 \\
0.02611 \\
0.02729 \\
\end{array}$ & $\begin{array}{c}22.55 \\
20.7 \\
21.93 \\
22.9\end{array}$ & $\begin{array}{c}9 \\
25 \\
17 \\
5\end{array}$ \\
\hline$R_{2}:$ construction risks & $\begin{array}{l}R_{21}: \text { type of excavation engineering } \\
R_{22}: \text { construction plan } \\
R_{23}: \text { construction quality } \\
R_{24}: \text { groundwater control } \\
R_{25}: \text { excavation monitoring construction impact } \\
\quad \text { on environment } \\
R_{26}: \text { new construction technique } \\
R_{27}: \text { not standardized construction } \\
R_{28}: \text { excessively rapid excavation and overcut }\end{array}$ & $\begin{array}{l}0.02441 \\
0.02616 \\
0.02614 \\
0.02588 \\
0.02522 \\
0.02711 \\
0.02428 \\
0.02444\end{array}$ & $\begin{array}{l}20.49 \\
21.97 \\
21.94 \\
21.73 \\
21.17 \\
22.8 \\
20.38 \\
20.52\end{array}$ & $\begin{array}{l}30 \\
15 \\
16 \\
20 \\
23 \\
6 \\
32 \\
29\end{array}$ \\
\hline$R_{3}:$ Economic risks & $\begin{array}{l}R_{31}: \text { project financing } \\
R_{32}: \text { contract performance }\end{array}$ & $\begin{array}{l}0.02618 \\
0.02377 \\
\end{array}$ & $\begin{array}{l}21.98 \\
19.96 \\
\end{array}$ & $\begin{array}{l}14 \\
36 \\
\end{array}$ \\
\hline$R_{4}:$ Management risks & $\begin{array}{l}R_{41}: \text { management of safety in construction } \\
R_{42}: \text { ability of skilled workers } \\
R_{43}: \text { construction management personnel } \\
R_{44}: \text { managerial experience shortage } \\
R_{45}: \text { not timely monitoring } \\
R_{46}: \text { poor communication } \\
R_{47}: \text { incomplete emergency plan } \\
R_{48}: \text { unsound administration system } \\
\end{array}$ & $\begin{array}{l}0.11909 \\
0.02398 \\
0.02600 \\
0.08685 \\
0.02620 \\
0.02684 \\
0.08685 \\
0.02637\end{array}$ & $\begin{array}{c}100 \\
20.14 \\
21.83 \\
72.9 \\
22.02 \\
22.55 \\
72.9 \\
22.14 \\
\end{array}$ & $\begin{array}{c}1 \\
35 \\
19 \\
3 \\
12 \\
9 \\
3 \\
11 \\
\end{array}$ \\
\hline$R_{5}:$ Design risk & $\begin{array}{l}R_{51}: \text { insufficient design theory foundation } \\
R_{52}: \text { shortage of experience for reference } \\
R_{53}: \text { not fully retaining and protection structure } \\
R_{54}: \text { ill-considered underground water and } \\
\quad \text { surrounding building } \\
R_{55}: \text { not comprehensively considered construction } \\
\quad \text { factors }\end{array}$ & $\begin{array}{l}0.02711 \\
0.02498 \\
0.02414 \\
0.02405 \\
0.02522 \\
\end{array}$ & $\begin{array}{l}22.74 \\
20.91 \\
20.27 \\
20.20 \\
21.17\end{array}$ & $\begin{array}{l}7 \\
26 \\
33 \\
34 \\
23\end{array}$ \\
\hline$R_{6}:$ Environmental risk & $\begin{array}{l}R_{61}: \text { unfavourable geological conditions } \\
R_{62}: \text { force majeure } \\
R_{63}: \text { surrounding huge building around } \\
R_{64}: \text { complicated underground pipe network } \\
R_{65}: \text { perturbation of the road nearby around }\end{array}$ & $\begin{array}{l}0.11644 \\
0.02577 \\
0.02708 \\
0.02457 \\
0.02372 \\
\end{array}$ & $\begin{array}{l}97.7 \\
21.63 \\
22.73 \\
20.63 \\
19.92\end{array}$ & $\begin{array}{c}2 \\
22 \\
8 \\
27 \\
37\end{array}$ \\
\hline$R_{7}:$ Survey risk & $\begin{array}{l}R_{71}: \text { error in the survey process } \\
R_{72}: \text { insufficient breadth and depth of survey } \\
R_{73}: \text { wrong testing method } \\
R_{74}: \text { calculation and parameter error } \\
R_{75}: \text { rock and soil and hydrological condition } \\
\quad \text { variation }\end{array}$ & $\begin{array}{l}0.02452 \\
0.02577 \\
0.02621 \\
0.02437 \\
0.02602\end{array}$ & $\begin{array}{l}20.58 \\
21.64 \\
22.02 \\
20.46 \\
21.85\end{array}$ & $\begin{array}{l}28 \\
21 \\
12 \\
31 \\
13\end{array}$ \\
\hline
\end{tabular}

\section{Conclusions}

Excavation project has become one of the most important and challenging issues in Shiraz as a developing city in Iran. In response to the rapid growth of urbanization and increased deep foundation, particularly for the critical infrastructure, the need for identify and assess significant risks has attracted much time and attention of excavation contractors, responsible sectors and government. In addition, the prediction and measurement of risk is difficult for stakeholders and decision makers to accurately measure because of the intangible nature of risk. The previous studies only used impact and frequency parameters to assess each risk. This paper introduced a developed new framework for ranking risks in excavation projects by SWARA-COPRAS method. The proposed model extended the conventional risk assessment model through introducing new criteria for ranking of risk. Twelve risk assessment criteria were identified from literature review and interview with expert. The weights of these criteria were obtained from SWARA method. The SWARA result showed that Threat $\left(C_{2}\right)$, Consequence $\left(C_{3}\right)$ and Risk manageability $\left(C_{10}\right)$ were the top three criteria with scores of $0.1346,0.1140$ and 0.1000 respectively. COPRAS method was used to obtain rank of risks based 
on criteria weight. Initially, 37 significant risks in excavation projects were identified and assessed. The COPRAS result showed that safety in construction risk $\left(R_{41}\right)$, unfavorable geological conditions risk $\left(R_{61}\right)$, managerial experience shortage risk $\left(R_{44}\right)$, incomplete emergency plan $\left(R_{47}\right)$ and subsidence of ground (R14) with scores of $0.1190,0.11644,0.0868,0.08598$ and 0.02729 , respectively, were five top risks in excavation projects in Shiraz. A comparison between COPRAS method and other decision making methods illustrated that COPRAS method is very useful when the number of alternatives and criteria are very high, because it does not need pair-wise comparison like FANP method and it does not contain complex calculations like Fuzzy method. This method can provide a complete ranking of alternatives and deal with both qualitative and quantitative problems and issues within one assessment. The finding of this study lays the foundation for risk management in excavation projects and construction companies are active in this area, particularly in Iran and developing countries, who are helped with monitoring and detection of risks in excavation projects, so as to reduce the possibility of accidence. This new hybrid multiple criteria decision making method can be useful in other sector of construction projects such as selection of the best area, the best type of contract and the best company for implementation of projects.

\section{Acknowledgement}

The work described in this paper has been fully supported by a joint grant from research grants PDRU (Malaysia, UTM Vote No. PY/2016/07174).

\section{References}

Al-Tmeemy, S. M. H.; Abdul-Rahman, H.; Harun, Z. 2012. Contractors' perception of the use of costs of quality system in Malaysian building construction projects, International Journal of Project Management 30(7): 827-838. https://doi.org/10.1016/j.ijproman.2011.12.001

Antucheviciene, J.; Kala, Z.; Marzouk, M.; Vaidogas, E. R. 2015. Solving civil engineering problems by means of fuzzy and stochastic MCDM methods: current state and future research, Mathematical Problems in Engineering, Article ID 560690. https://doi.org/10.1155/2015/362579

Aven, T. 2015. Implications of black swans to the foundations and practice of risk assessment and management, Reliability Engineering \& System Safety 134: 83-91. https://doi.org/10.1016/j.ress.2014.10.004

Aven, T. 2016. Risk assessment and risk management: review of recent advances on their foundation, European Journal of Operational Research 253(1): 1-13. https://doi.org/10.1016/j.ejor.2015.12.023

Bo, L.; Kaiqiang, W.; Mian, H.; Peige, H.; Hongjie, Z. 2015. Research on fuzzy hierarchical risk assessment of metro deep excavation pit, Chinese Journal of Underground Space and Engineering 11(S1).

Burcar Dunovic, I.; Radujkovic, M.; Vukomanovic, M. 2016. Internal and external risk based assessment and evaluation for the large infrastructure projects, Journal of Civil Engineering and Management 22(5): 673-682. https://doi.org/10.3846/13923730.2015.1128479
Chiew, S. P.; Yu, Y. 2006. Behaviour of strut-waler connections with different stiffening details, The Structural Engineer 84(14).

Feng, R.; Jun-yan, L. 2011. Fuzzy assessment on risk of deep excavation engineering, in Asia-Pacific Power and Energy Engineering Conference, March 2011. https://doi.org/10.1109/appeec.2011.5748781

He, X. X.; Zhou, H. B.; Yao, H. 2006. Construction risk identification and assessment of a deep foundation pit in Shanghai, Chinese Journal of Geotechnical Engineering 28: 1912-1915.

Hong, Q. K.; Wang, J. B.; Ge, J.; Chen, P. 2013. Research on the risk of deep foundation excavation engineering management based on RBS and AHP, Applied Mechanics and Materials 438: 1010-1014. https://doi.org/10.4028/www. scientific.net/amm.438-439.1010

Huang, H. W.; Bian, Y. H. 2005. Risk management in the construction of deep excavation engineering, Chinese Journal of Underground Space and Engineering 1(4): 611-614.

Iqbal, S.; Choudhry, R. M.; Holschemacher, K.; Ali, A.; Tamošaitiené, J. 2015. Risk management in construction projects, Technological and Economic Development of Economy 21(1): 65-78. https://doi.org/10.3846/2029491 3.2014 .994582

Jian, H.; HaiZe, P.; MengJie, C.; Wei, M. 2016. Construction risk of foundation pit of subway station based on Rough Set theory and Catastrophe Progression method, Electronic Journal of Geotechnical Engineering 21: 1615-1628.

Karabasevic, D.; Stanujkic, D.; Urosevic, S.; Maksimovic, M. 2015. Selection of candidates in the mining industry based on the application of the SWARA and the MULTIMOORA methods, Acta Montanistica Slovaca 20(2): 116-124.

Keršuliene, V.; Turskis, Z. 2011. Integrated fuzzy multiple criteria decision making model for architect selection, Technological and Economic Development of Economy 17(4): 645-666. https://doi.org/10.3846/20294913.2011.635718

Keršulienè, V.; Zavadskas, E. K.; Turskis, Z. 2010. Selection of rational dispute resolution method by applying new stepwise weight assessment ratio analysis (SWARA), Journal of Business Economics and Management 11(2): 243-258. https://doi.org/10.3846/jbem.2010.12

Khosravizade, A.; Sharifipour, M. 2016. Subway risks assessment in different construction stages using AHP and TOPSIS, Indian Journal of Science and Technology 9(7). https://doi.org/10.17485/ijst/2016/v9i7/87859

Kundakc1, N.; Işık, A. 2016. Integration of MACBETH and COPRAS methods to select air compressor for a textile company, Decision Science Letters 5(3): 381-394. https://doi.org/10.5267/j.dsl.2016.2.003

Leonavičiūtè, G.; Dejjus, T.; Antuchevičienè, J. 2016. Analysis and prevention of construction site accidents, Građevinar 68(5): 399-410.

Li, Y.; Wang, C. 2010. Based on the Delphi method of deep excavation safety risk analysis, in 2010 International Conference on IEEE Artificial Intelligence and Education (ICAIE), 347-349. https://doi.org/10.1109/icaie.2010.5641503

Mulliner, E.; Malys, N.; Maliene, V. 2016. Comparative analysis of MCDM methods for the assessment of sustainable housing affordability, Omega 59: 146-156. https://doi.org/10.1016/j.omega.2015.05.013

Nakhaei, J.; Lale Arefi, S.; Bitarafan, M.; Kapliński, O. 2016. Model for rapid assessment of vulnerability of office buildings to blast using SWARA and SMART methods (a case study of Swiss Re Tower), Journal of Civil Engineering and Management 22(6): 831-843. https://doi.org/10.3 846/13923730.2016.1189457 
Sarvari, H.; Valipour, A.; Nordin, Y.; Norhazilan, M. N. 2014. Risk ranking of Malaysian Public Private Partnership projects, Applied Mechanics and Materials 567: 613-618. https://doi.org/10.4028/www.scientific.net/amm.567.613

Shahata, K.; Zayed, T. 2015. Integrated risk-assessment framework for municipal infrastructure, Journal of Construction Engineering and Management 142(1), 04015052. https://doi.org/10.1061/(ASCE)CO.1943-7862.0001028

Tamošaitienè, J.; Zavadskas, E. K.; Turskis, Z. 2013. Multicriteria risk assessment of a construction project, Procedia Computer Science 17: 129-133. https://doi.org/10.1016/j.procs.2013.05.018

Turskis, Z.; Daniūnas, A.; Zavadskas, E. K.; Medzvieckas, J. 2016. Multicriteria evaluation of building foundation alternatives, Computer-Aided Civil and Infrastructure Engineering 31(9): 717-729. https://doi.org/10.1111/mice.12202

Valipour, A.; Yahaya, N.; Md Noor, N.; Kildienè, S.; Sarvari, H.; Mardani, A. 2015. A fuzzy analytic network process method for risk prioritization in freeway PPP projects: an Iranian case study, Journal of Civil Engineering and Management 21(7): 933-947. https://doi.org/10.3846/139237 30.2015 .1051104

Wang, X. M. 2008. Fifty millions RMB will be compensated to Hangzhou Metro for the accident by six insurance agents [online], [cited 30 Oct 2008]. Available from Internet: http://news. $21 \mathrm{cn} . \mathrm{com} /$ domestic/ difang/2008/11/19/5491008_1.shtml

Yang, Z.; Yang, J.; Yang, Y. 2004. Research on foundation excavation project risk management, Science and Technology Information Development \& Economy 9: 205-207.

Zavadskas, E. K.; Kaklauskas, A. 1996. Determination of an efficient contractor by using the new method of multicriteria assessment, in International Symposium for the Organization and Management of Construction. Shaping Theory and Practice, Vol. 2: Managing the Construction
Project and Managing Risk, CIB W 65, London, Weinheim, New York, Tokyo, Melbourne, Madras, London: E and FN SPON, 94-104.

Zavadskas, E. K.; Turskis, Z.; Tamošaitienè, J. 2010. Risk assessment of construction projects, Journal of Civil Engineering and Management 16(1): 33-46. https://doi.org/10.3846/jcem.2010.03

Zegordi, S. H.; Nik, E. R.; Nazari, A. 2012. Power plant project risk assessment using a fuzzy-ANP and fuzzy-TOPSIS method, International Journal of Engineering-Transactions B: Applications 25(2): 107-120. https://doi.org/10.5829/idosi.ije.2012.25.02b.04

Zhang, D. S.; Li, Y. B. 2008. Four others works are still missing in the accident of Hangzhou Metro construction, and special organization is established to investigate the accident [online], [cited 30 Oct 2008]. Available from Internet: http://society.people.com.cn/GB/41158/8435699.html

Zhang, J. 2010. Dynamic risk analysis based on entropy measurement for the construction of deep excavation engineering, in The $2^{\text {nd }}$ International Conference on Information Science and Engineering, IEEE, 2805-2808. https://doi.org/10.1109/icise.2010.5691503

Zhang, L.; Wu, X.; Ding, L.; Skibniewski, M. J.; Lu, Y. 2016. Bim-based risk identification system in tunnel construction, Journal of Civil Engineering and Management 22(4): 529-539. https://doi.org/10.3846/13923730.2015.1023348

Zhou, H. B.; Yao, H.; Lu, J. H. 2006. Construction risk assessment on deep foundation pits of a metro line in Shanghai, Chinese Journal of Geotechnical Engineering 28: 1902 1906.

Zhou, H. B.; Zhang, H. 2011. Risk assessment methodology for a deep foundation pit construction project in Shanghai, China, Journal of Construction Engineering and Management 137(12): 1185-1194. https://doi.org/10.1061/(asce) co.1943-7862.0000391

Alireza VALIPOUR. PhD, Post Doctorate fellowship at the Faculty of Civil Engineering of Universiti Teknologi Malaysia (UTM) and lecture in Shiraz branch Azad University. His main research interests include the application of multiple criteria decision making theories in construction management, construction technology, project management and risk management.

Nordin YAHAYA. PhD, Professor, Faculty of Civil Engineering, Universiti Teknologi Malaysia (UTM). He has also been appointed as the Senior Director of UTM International. Research interests: multi criteria decision making theories in construction management, project management, PPP risk management and pipeline Soil-Corrosion Integrity Assessment.

Norhazilan MOHAMAD NOOR. PhD, Associate Professor, Faculty of Civil Engineering, Universiti Teknologi Malaysia (UTM). Research interests: multi criteria decision making theories in construction management, project management, PPP risk management and pipeline Soil-Corrosion Integrity Assessment.

Jurgita ANTUCHEVIČIENĖ. PhD, Professor, Department of Construction Technology and Management, Vilnius Gediminas Technical University, Vilnius, Lithuania. Research interests include multiple criteria analysis, decision-making theories and decision support systems, sustainable development, construction management and investment.

Jolanta TAMOŠAITIENĖ. PhD, Vice-Dean of Civil Engineering Faculty, Associated Professor, Department of Construction Technology and Management, Vilnius Gediminas Technical University, Vilnius, Lithuania. Research interests: many miscellaneous management areas (enterprise, construction project and etc.), risk assessment, construction project administration, building life-cycle, construction technology and organisation, decision-making and grey system theory, Decision Making (DM), statistics, optimization, strategies, game theory, intelligent support system, Sustainable Development: developing of alternative construction processes, economic and other aspects, sustainable development challenges for business and management in construction enterprises, environmental impact processes and etc. 